DOI: 10.38136/jgon.903783

\title{
Maternal, fetal, and neonatal outcomes of pregnancies in adolescents and women of advanced age: Ten-year experience of a tertiary referral center
}

\section{Adelösan ve ileri yaş gebeliklerin maternal, fetal ve neonatal sonuçları: üçüncü basamak referans merkezin on yıllık deneyimi}

\author{
Irem Alyazıcl KÜÇÜKYILDIZ \\ Dilay KARADEMIR \\ Nazan YURTCU \\ Illkin Seda CAN \\ Tahsin TAKCi \\ Ali ÇETIN
}

(1) Orcid ID:0000-0002-6604-0713

(1) Orcid ID:0000-0002-9813-4255

(1) Orcid ID:0000-0003-4725-043x

(1) Orcid ID:0000-0002-2029-7281

(1) Orcid ID:0000-0003-1709-1597

${ }^{1}$ Cumhuriyet University School of Medicine, Department of Obstetrics and Gynecology, Sivas, Turkey

\section{Öz}

Amaç: Bu çalışmada Orta Anadolu'da bulunan üçüncü basamak sevk merkezinin son on yılda takip ettiği adelösan ve ileri yaştaki gebeliklerin maternal, fetal ve neonatal sonuçlarını değerlendirmeyi amaçladık.

Gereç ve Yöntemler: 2011-2020 yılları arasında üçüncü basamak sevk merkezimizin kadın hastalıkları biriminde doğum yapan 414 adelösan (10-19 yaş), 428 ileri yaş ( $\geq 40$ yaş) ve kontrol grubu olan 150 gebenin (20-39 yaş) hastane elektronik kayıtlarından anne ve yenidoğan verilerini topladık.

Bulgular: Yaşamın erken veya geç dönemlerinde çocuk sahibi olan kadınlarda saptadığımız obstetrik ve fetal sonuçlarımıza göre; ileri yaştaki kadınlarda bir veya üzeri parite olması, sezaryen doğum yöntemi, gestasyonel hipertansiyon ve akut fetal distres oranları kontrol gruba göre anlamlı olarak daha yüksek iken $(p<0.05)$, adelösanlarda bir veya üzeri parite olması, sezaryen doğum yöntemi, gestasyonel diyabet ve > 34 gebelik haftası doğum oranları kontrol grubu göre anlamlı olarak düşük bulundu $(p<0.05)$

Sonuç: Bulgularımız, adelösan ve ileri yaş ( $\geq 40$ yaş) gebeliklerde perinatal ve neonatal istatistiklerinin iyileştiğini desteklemektedir. Bununla birlikte, sağlık hizmeti koşullarında, annelerin ve sağık çalışanlarının gebelikle ilgili hastalıklar - ölümler hakkında farkındalıklarında ve eğitim - öğretim programlarının uygulanmasında daha fazla ilerlemeye intiyaç vardır.

Anahtar Kelimeler: obstetrik sonuçlar, neonatal sonuçlar, adelösan, ileri anne yaşı, Türkiye

\section{INTRODUCTION}

There is a changing trend related to the age of pregnant women. At the extremes of maternal age as adolescent and advanced age, pregnancy causes considerably increased maternal, fetal, and neonatal morbidity and mortality. To improve obstetric outcomes of pregnancies in the adolescent and women of advanced age, there is a need to assess obs-

\section{ABSTRACT}

Aim: In this study, we aimed to evaluate the maternal, fetal and neonatal outcomes of adolescent and advanced age pregnancies followed by a tertiary referral center in Central Anatolia in the last decade.

Materials and Methods: In this retrospective study, we collected the maternal and neonatal data from the hospital electronic records of 414 adolescents (10-19 years of age), 428 women of advanced age ( $\geq 40$ years of age), and 150 pregnant controls (20-39 years of age) who delivered in the obstetrics unit of our tertiary referral center between 2011 and 2020.

Results: Obstetric and fetal outcomes affected from women bearing children early or late stages in life. According to our results, rates of one or more parity, cesarean section, gestational hypertension, and acute fetal distress in the women of advanced age were significantly higher than those in the controls $(p<0.05)$. The rates of one or more parity, cesarean section, gestational diabetes and $>34$ gestational weeks in the adolescents were significantly lower than those in the controls $(p<0.05)$.

Conclusion: Our findings support the improving perinatal and neonatal statistics of pregnancies in adolescents and women of advanced age ( $\geq 40$ years). Nevertheless, there is a need further advancements in healthcare conditions and awareness of mothers and healthcare workers about pregnancy related morbidities and mortalities and applying educational and training programs.

Keywords: obstetric outcomes, neonatal outcomes, adolescence, advanced maternal age, Turkey

tetric data to compare with finding of previous reports and to develop new strategies for forwarding perinatal care and continuing education of health workers. Both Adolescent pregnancies and advanced age pregnancies are high-risk pregnancies that cause important maternal - fetal social and health problems $(1,2,3,4)$. Generally, preterm delivery, low birthweight babies, and cesarean delivery rates are high in both groups. 
KÜÇÜK YILDIZ A.I. 946

The World Health Organization (WHO) accepts adolescent period between 10-19 years of age and according to the WHO report, approximately 12 million girls aged $15-19$ years and at least 777,000 girls under 15 years give birth each year in developing regions $(5,6)$. For low- and middle-income countries, although they have been in a downward trend for the last 20-30 years, adolescent pregnancies are still one of important causes for high risk pregnancy (7).

Especially in developed countries, career planning of women, desire to achieve financial stability and advances in assisted reproductive techniques, cause maternal average age at first birth to increase and shift to their late $35 \mathrm{~s}, 40 \mathrm{~s}(1,2)$. For most researchers, although the definition of advanced maternal age is 35 years and older, it is frequently defined as advanced maternal age above 40 years in the medical literature (1). The average age at first birth has been increasing worldwide in recent years. The mean age of mothers increased 2.6 years in the past three decades from 21 to 25 years in United State (8). In other western countries the trend was similar, there are studies showing that maternal age increases and averaging near 30 years of age in Sweden, Switzerland, Denmark and England $(9,10)$.

According Turkey Demographic and Health Survey $12.1 \%$ and $8.6 \%$ of women, respectively, have their first birth under the age of 18 and above the $\geq 35$ years (11). There is no study investigating the recent stata of pregnancies in adolescents and women of advanced stage in Sivas province in our country. The aim of this study was to evaluate maternal, fetal, and neonatal outcomes of pregnancies in adolescents and women of advanced age during last decade in a tertiary referral center. We think that the local findings obtained from this research can create predictions in terms of maternal-neonatal outcomes for urban regions with similar demographic characteristics.

\section{MATERIALS AND METHODS}

In this retrospective study, we obtained the maternal and neonatal data from the hospital electronic records of 414 adolescents (10-19 years of age), 428 women of advanced age ( $\geq 40$ years of age), and 150 pregnant controls (20-39 years of age) who delivered in the obstetrics unit of Sivas Cumhuriyet University between 2011 and 2020. Approximately 11000 births were performed in 10 years of study period in our institution. Among these births, the rates of pregnancies in adolescents and women of advanced age is approximately $3.8 \%$ and $3.9 \%$, respectively. The control group of the study was formed by ran- dom selection from women who gave birth between the ages of 20-39. All adolescent and advanced age pregnant women were included in the study, no exclusion criteria were applied for the control group except maternal age.

The major maternal, fetal, and neonatal parameters were collected including parity, presentation of fetus, multıple pregnancy, medical disorder associated with pregnancy (hypertension in pregnancy and gestational diabetes) and mode of delivery (normal vaginal delivery, and cesarean section). The perinatal parameters recorded as the birth weight, birth outcomes (whether live birth or still birth) and Apgar score at 1 and 5 minutes of life. This study was conducted according to the principles stated in the Declaration of Helsinki and it was approved by the Human Research Ethics Committee of the Sivas Cumhuriyet University (registry no: 2020-05/16).

Statistical evaluation was performed with SPSS version 23 software (USA). Kolmogorov-Smirnov test was used to evaluate distribution of numeric variables. Independent $t$ test was used to test the significance of the difference between pairs. Categorical variables were compared using the chi-square test or Fisher's exact test. Odds ratios and their corresponding 95\% confidence intervals $(\mathrm{Cl})$ were used to describe the association between two categorical variables with significance obtained at $5 \%$. The effect of variables on groups was evaluated with binary logistic regression analysis. Differences were considered statistically significant at a $p$ value $<0.05$.

\section{RESULTS}

The study was completed with 414 adolescents, 428 older women, and 150 controls and their perinatal, natal, and neonatal characteristics were analyzed. Table 1 presents the pregnancy-related characteristics of controls, adolescents, and women of advanced age. As expected, the rates of one or more parity and cesarean section in the women of advanced age were significantly higher than those in the controls and adolescents; and the rates of one or more parity and cesarean section in controls were significantly higher than that in the adolescents $(p<0.05)$. The most important reason why cesarean delivery is more common in the women of advanced age is due to the more rate of repeated cesarean sections. While the rate of repeated cesarean section was $30 \%$ in the women of advanced age, it was $10 \%$ in adolescents and $27 \%$ in the control group. There was no significant difference among the study groups with regard to the rates of multiple pregnancy and vertex presentation $(p>0.05)$. 
Although the rate of stillbirth was higher in the women of advanced age compared to those of the controls and adolescents, the difference did not reach statistical significance $(p>0.05)$.

Table 1 Pregnancy-related characteristic

\begin{tabular}{|l|l|l|l|}
\hline & $\begin{array}{l}\text { Controls } \\
(\mathrm{n}=150)\end{array}$ & $\begin{array}{l}\text { Adolescents } \\
(\mathrm{n}=414)\end{array}$ & $\begin{array}{l}\text { Women of } \\
\text { advanced } \\
\text { age } \\
(\mathrm{n}=428)\end{array}$ \\
\hline Age (y) & 41.5 & 18.2 & 26.8 \\
\hline Parity & & & \\
\hline 0 & $54(36 \%)$ & $362(87.5 \%)$ & $45(10.5 \%)$ \\
\hline 1 or more & $96(64 \%)^{\mathrm{c}}$ & $52(12.5 \%)^{\mathrm{a}}$ & $383(89.5 \%)^{\mathrm{b}}$ \\
\hline Multiple pregnancy & & & \\
\hline No & $144(96 \%)$ & $401(96.9 \%)$ & $420(98.1 \%)$ \\
\hline Yes & $6(4 \%)^{\mathrm{a}}$ & $13(3.1 \%)^{\mathrm{a}}$ & $8(1.9 \%)^{\mathrm{a}}$ \\
\hline $\begin{array}{l}\text { Stillbirth }(\geq 20 \text { gesta- } \\
\text { tional week) }\end{array}$ & & & \\
\hline No & $148(98.7 \%)$ & $401(96.9 \%)$ & $406(94.8 \%)$ \\
\hline Yes & $2(1.3 \%)^{\mathrm{a}}$ & $13(3.1 \%)^{\mathrm{a}}$ & $22(5.2 \%)^{\mathrm{a}}$ \\
\hline Methods of delivery & & & \\
\hline Vaginal delivery & $58(38.7 \%)$ & $208(50.2 \%)$ & $112(26.2 \%)$ \\
\hline Cesarean section & $92(61.5 \%)^{\mathrm{c}}$ & $206(49.8 \%)^{\mathrm{a}}$ & $316(73.8 \%)^{\mathrm{b}}$ \\
\hline Fetal Presentation & & & \\
\hline Vertex & $135(90 \%)$ & $365(88.2 \%)$ & $397(92.8 \%)$ \\
\hline Others & $15(10 \%)^{\mathrm{a}}$ & $49(11.8 \%)^{\mathrm{a}}$ & $31(7.2 \%)^{\mathrm{a}}$ \\
\hline & & & \\
\hline Data are expressed as number & & \\
\hline
\end{tabular}

Data are expressed as number (\%) and analyzed with chi-square test. Same superscript letter denotes a subset of subgroups whose column rates do not differ significantly from each other at the adjusted $p$ value with Bonferroni correction ( $p>0.05)$.

Table 2 shows maternal outcomes of controls, adolescents, and women of advanced age. The rate of gestational diabetes in the adolescents was significantly lower than those in the controls and women of advanced age $(p<0.05)$; and the rates of gestational diabetes in the controls and women of advanced age were comparable $(p>0.05)$. The rates of gestational hypertension and acute fetal distress in the women of advanced age were significantly higher than that in the controls $(p<0.05)$; and the rates of gestational hypertension and acute fetal distress were found as similar in the adolescents and o women of advanced age and in the adolescents and controls ( $p>0.05)$. The rate of preeclampsia in the women of advanced age was significantly higher than that in the adolescents $(p<0.05)$; and the rates of preeclampsia were found as similar in the women of advanced age and controls and in the adolescents and controls ( $p>0.05$ ). The rate premature membrane rupture in the women of advanced age were significantly lower than that in the adolescents $(p<0.05)$; and the rates of premature membrane rupture were found as similar in the women of advanced age and controls and in the adolescents and controls ( $p>0.05)$. There was no significant difference among the study groups with regard to the rates of placental abruption and placenta previa ( $p>0.05)$.

Table 2 Obstetrical complications

\begin{tabular}{|c|c|c|c|}
\hline & $\begin{array}{l}\text { Controls } \\
(n=150)\end{array}$ & $\begin{array}{l}\text { Adoles- } \\
\text { cents } \\
(n=414)\end{array}$ & $\begin{array}{l}\text { Women of ad- } \\
\text { vanced age } \\
(n=428)\end{array}$ \\
\hline $\begin{array}{l}\text { Gestational dia- } \\
\text { betes } \\
\text { No } \\
\text { Yes }\end{array}$ & $\begin{array}{l}143 \\
(95.3 \%) \\
7(4.7 \%)^{\mathrm{b}}\end{array}$ & $\begin{array}{l}409 \\
(98.8 \%) \\
5(1.2 \%)^{a}\end{array}$ & $\begin{array}{l}385(90 \%) \\
43(10 \%)^{b}\end{array}$ \\
\hline $\begin{array}{l}\text { Gestational hyper- } \\
\text { tension } \\
\text { No } \\
\text { Yes }\end{array}$ & $\begin{array}{l}145 \\
(96.7 \%) \\
5(3.3 \%)^{a}\end{array}$ & $\begin{array}{l}373 \\
(90 \%) \\
41(10 \%) \\
a, b\end{array}$ & $\begin{array}{l}381(89 \%) \\
47(11 \%)^{b}\end{array}$ \\
\hline $\begin{array}{l}\text { Preeclampsia } \\
\text { No } \\
\text { Yes }\end{array}$ & $\begin{array}{l}142 \\
(94.7 \%) \\
8(5.3 \%) \\
a, b\end{array}$ & $\begin{array}{l}390 \\
(94.2 \%) \\
24 \\
(5.8 \%)^{a}\end{array}$ & $\begin{array}{l}383(89.5 \%) \\
45(10.5 \%)^{b}\end{array}$ \\
\hline $\begin{array}{l}\text { Placental abruption } \\
\text { No } \\
\text { Yes }\end{array}$ & $\begin{array}{l}148 \\
(98.7 \%) \\
2(1.3 \%)^{a}\end{array}$ & $\begin{array}{l}413 \\
(99.8 \%) \\
1(0.2 \%)^{a}\end{array}$ & $\begin{array}{l}420(98.1 \%) \\
8(1.9 \%)^{a}\end{array}$ \\
\hline $\begin{array}{l}\text { Placenta previa } \\
\text { No } \\
\text { Yes }\end{array}$ & $\begin{array}{l}146 \\
(97.3 \%) \\
4(2.7 \%)^{a}\end{array}$ & $\begin{array}{l}409 \\
(98.8 \%) \\
5(1.2 \%)^{a}\end{array}$ & $\begin{array}{l}417(97.4 \%) \\
11(2.6 \%)^{a}\end{array}$ \\
\hline $\begin{array}{l}\text { Premature memb- } \\
\text { rane rupture } \\
\text { No } \\
\text { Yes }\end{array}$ & $\begin{array}{l}142 \\
(94.7 \%) \\
8(5.3 \%) \\
a, b\end{array}$ & $\begin{array}{l}379 \\
(91.5 \%) \\
35 \\
(8.5 \%)^{a}\end{array}$ & $\begin{array}{l}410(95.8 \%) \\
18(4.2 \%)^{b}\end{array}$ \\
\hline $\begin{array}{l}\text { Acute fetal distress } \\
\text { No } \\
\text { Yes }\end{array}$ & $\begin{array}{l}146 \\
(97.3 \%) \\
4(2.7 \%)^{a}\end{array}$ & $\begin{array}{l}379 \\
(91.5 \%) \\
35 \\
(8.5 \%)^{a, b}\end{array}$ & $\begin{array}{l}380(88.8 \%) \\
48(11.2 \%)^{b}\end{array}$ \\
\hline
\end{tabular}

Data are expressed as number (\%) and analyzed with chi-square test. Same superscript letter denotes a subset of subgroups whose column rates do not differ significantly from each other at the adjusted $p$ value with Bonferroni correction ( $p>0.05)$. 
Table 3 displays fetal outcomes of controls, adolescents, and women of advanced age. The rate of median birth weight in the adolescents was significantly lower than those in the controls and women of advanced age $(p<0.05)$; and the rates of median birth weight in the controls and women of advanced age were comparable $(p>0.05)$. The rate of early preterm labor ( $\leq 34$ gestational weeks) in the adolescents was significantly higher than those in the controls and women of advanced age $(p<0.05)$; and the rates of early preterm labor in the controls and women of advanced age were comparable ( $p>0.05)$. Although the rate of early preterm labor was higher in the women of advanced age compared to that of the controls, the difference did not reach statistical significance $(p>0.05)$. When fetal anomaly, females gender, Apgar 1min., and Apgar 5 min. parameters were examined, no difference was found between the groups $(p>0.05)$.

Table 3 Neonatal characteristics

\begin{tabular}{|c|c|c|c|}
\hline & $\begin{array}{l}\text { Controls } \\
(n=150)\end{array}$ & $\begin{array}{l}\text { Adolescents } \\
(n=414)\end{array}$ & $\begin{array}{l}\text { Women of } \\
\text { advanced } \\
\text { age } \\
(n=428)\end{array}$ \\
\hline $\begin{array}{l}\text { Fetal ano- } \\
\text { maly } \\
\text { No } \\
\text { Yes }\end{array}$ & $\begin{array}{l}147(98 \%) \\
3(2 \%)^{\mathrm{a}}\end{array}$ & $\begin{array}{l}407(98.3 \%) \\
7(1.7 \%)^{a}\end{array}$ & $\begin{array}{l}419(97.9 \%) \\
9(2.1 \%)^{a}\end{array}$ \\
\hline $\begin{array}{l}\text { Gender } \\
\text { Female } \\
\text { Male }\end{array}$ & $\begin{array}{l}66(42.5 \%)^{\mathrm{a}} \\
89(57.5 \%)\end{array}$ & $\begin{array}{l}200(47 \%)^{a} \\
225(53 \%)\end{array}$ & $\begin{array}{l}209(49.4 \%)^{2} \\
214(50.6 \%)\end{array}$ \\
\hline $\begin{array}{l}\text { Weight } \\
\leq 1500 \mathrm{gr} \\
\geq 4000 \mathrm{gr} \\
\text { Weight, g }\end{array}$ & $\begin{array}{l}9(6 \%) \\
10(6.6 \%) \\
3020 \pm 786.1\end{array}$ & $\begin{array}{l}41 \text { (9.9\%) } \\
15(3.6 \%) \\
2745 \pm 808.1\end{array}$ & $\begin{array}{l}22(5.1 \%) \\
47(10.9 \%) \\
3101 \pm 826.9\end{array}$ \\
\hline $\begin{array}{l}\text { Gestatio- } \\
\text { nal age } \\
\leq 34 \text { we- } \\
\text { eks } \\
>34 \text { we- } \\
\text { eks } \\
\text { Weeks, w }\end{array}$ & $\begin{array}{l}20(13.3 \%)^{\mathrm{b}} \\
130(86.7 \%) \\
38 \pm 3.1\end{array}$ & $\begin{array}{l}116(28 \%)^{a} \\
298(72 \%) \\
36.36 \pm 3.9\end{array}$ & $\begin{array}{l}70(16.4 \%)^{b} \\
358(83.6 \%) \\
36.73 \pm 3.3\end{array}$ \\
\hline $\begin{array}{l}\text { Apgar } 1 \\
\text { min. }\end{array}$ & $8.5 \pm 1.5$ & $7.75 \pm 2.1$ & $8.91 \pm 2$ \\
\hline $\begin{array}{l}\text { Apgar } 5 \\
\text { min. }\end{array}$ & $10 \pm 1.5$ & $7.73 \pm 4.5$ & $8.7 \pm 2.2$ \\
\hline
\end{tabular}

Data are expressed as number (\%) and analyzed with chi-square test. Same superscript letter denotes a subset of subgroups whose column rates do not differ significantly from each other at the adjusted $p$ value with Bonferroni correction ( $p>0.05)$.
Table 4 presents the multivariate analysis of clinical variables in the adolescents and women of advanced age. Adolescents had 2.4 times more often nulliparity, 2.5 times more often gestational hypertension, 3.1 times more often acute fetal distress, 1.9 times more often early preterm labor than the controls. Adolescents had 0.8 less often cesarean section and 0.2 times less often gestational diabetes, than the controls. Women of advanced age had 1.2 times more often cesarean section, 3.9 times more often stillbirth, 2.8 more often gestational hypertension and 4.1 times more often acute fetal distress, than the controls. Women of advanced age had 0.3 time less often nulliparity than the controls.

Table 4a Multivariate analysis of clinical variables in the adolescents

\begin{tabular}{|c|c|c|}
\hline & \multicolumn{2}{|c|}{ Adolescents } \\
\hline & $\begin{array}{l}\text { Odds } \\
\text { ratio }\end{array}$ & Significance \\
\hline Parity (nulliparity) & 2.4 & $<0.001$ \\
\hline Cesarean section (yes/no) & 0.8 & 0.01 \\
\hline Gestational diabetes (yes/no) & 0.2 & 0.004 \\
\hline Gestational hypertension (yes/no) & 2.5 & 0.02 \\
\hline Acute fetal distress (yes/no) & 3.1 & 0.02 \\
\hline Gestational age ( $\leq 34$ weeks) & 1.9 & 0.002 \\
\hline
\end{tabular}

Table $4 \mathrm{~b}$ Multivariate analysis of clinical variables in the women of advanced age

\begin{tabular}{|l|l|l|}
\hline & \multicolumn{2}{l|}{$\begin{array}{l}\text { Women of advanced } \\
\text { age. }\end{array}$} \\
\hline & $\begin{array}{l}\text { Odds } \\
\text { ratio }\end{array}$ & Significance \\
\hline Parity (nulliparity) & 0.3 & $<0.001$ \\
\hline Cesarean section (yes/no) & 1.2 & 0.004 \\
\hline Stillbirth (yes/no) & 3.9 & 0.04 \\
\hline Gestational hypertension (yes/no) & 2.8 & 0.009 \\
\hline Acute fetal distress (yes/no) & 4.1 & 0.002 \\
\hline
\end{tabular}

Table $\mathbf{5}$ shows binary logistic regression coefficients of independent clinical variables regarding the age of participants. As maternal age increases, the probability of cesarean section, $\leq 34$ weeks of gestation birth, stillbirth, gestational hypertension and female gender increase $(p<0.05)$. As the maternal age increases, the possibility of having multiple pregnancy decreases $(p<0.05)$. No contribution of maternal age was detected to the rates of multiparity, fetal presentation type, preeclampsia, placental abruption, placenta previa, premature membrane rupture, acute fetal distress, gestational diabetes, and fetal anomaly $(p>0.05)$. 
Table 5: Binary logistic regression coefficients of age groups by independent variables.

\begin{tabular}{|c|c|c|c|c|c|c|c|c|}
\hline \multirow[t]{2}{*}{$\begin{array}{l}\text { Independent } \\
\text { variables }\end{array}$} & \multirow[t]{2}{*}{ B } & \multirow[t]{2}{*}{ SE } & \multirow[t]{2}{*}{ Wald } & \multirow[t]{2}{*}{$d f$} & \multirow[t]{2}{*}{ Sig. } & \multirow[t]{2}{*}{$\operatorname{Exp}(B)$} & \multicolumn{2}{|c|}{$\begin{array}{l}\text { 95\% C.I.for } \\
\operatorname{EXP(B)} \\
\end{array}$} \\
\hline & & & & & & & Lower & Upper \\
\hline \multirow{2}{*}{$\begin{array}{l}\text { Cesarean } \\
\text { section }\end{array}$} & 0.576 & 0.201 & 8.249 & 1 & 0.004 & 1.779 & 1.201 & 2.635 \\
\hline & 0.461 & 0.168 & 7.571 & 1 & 0.006 & 1.586 & - & - \\
\hline \multirow{2}{*}{$\begin{array}{l}\text { Gestational } \\
\text { hypertension }\end{array}$} & 1.109 & 0.444 & 6.242 & 1 & 0.012 & 3.032 & 1.270 & 7.237 \\
\hline & -3.178 & 0.417 & 58.176 & 1 & 0.000 & 0.042 & - & - \\
\hline \multirow{2}{*}{$\begin{array}{l}\text { Gestational } \\
\text { age ( } \leq 34 \\
\text { weeks) }\end{array}$} & -0.222 & 0.274 & 0.655 & 1 & 0.418 & 0.801 & 0.468 & 1.371 \\
\hline & 1.872 & 0.240 & 60.730 & 1 & 0.000 & 6.500 & - & - \\
\hline \multirow{2}{*}{$\begin{array}{l}\text { Multiple } \\
\text { pregnancy }\end{array}$} & -0.783 & 0.549 & 2.036 & 1 & 0.154 & 0.457 & 0.156 & 1.340 \\
\hline & -3.178 & 0.417 & 58.176 & 1 & 0.000 & 0.042 & - & - \\
\hline \multirow[t]{2}{*}{ Stillbirth } & 1.389 & 0.745 & 3.477 & 1 & 0.062 & 4.010 & 0.932 & 17.261 \\
\hline & -4.304 & 0.712 & 36.556 & 1 & 0.000 & 0.014 & - & - \\
\hline \multirow{2}{*}{$\begin{array}{l}\text { Female gen- } \\
\text { der }\end{array}$} & -0.277 & 0.193 & 2.073 & 1 & 0.150 & 0.758 & 0.519 & 1.105 \\
\hline & 0.311 & 0.166 & 3.522 & 1 & 0.061 & 1.365 & - & - \\
\hline
\end{tabular}

B - beta value; SE - standard error; Wald - method of computing multiple regression; df - degrees of freedom; Sig -significance; C.I.confidence interval; ExpB - exponential beta

\section{DISCUSSION}

In this study, we found that considerable influences of extremes of maternal age on maternal, fetal, and neonatal outcomes.

The most important difference of our study from previous studies; is the comparing of two extreme groups of maternal age with the control group and also with each other.

According to our results, rates of one or more parity, cesarean section, gestational hypertension, and acute fetal distress in the women of advanced age were significantly higher than those in the controls. On the other hand, the rates of one or more parity, cesarean section, gestational diabetes and early preterm labor in the adolescents were significantly lower than those in the controls. When the literature was examined, the pregnancy-related characteristics such as nulliparity and cesarean section and fetal outcomes including low baby weight, preterm delivery of adolescent and older women were found to be similar to those in this study $(3,4,12,13,14)$. In addition, as maternal age increases, pregnancies carry greater probabilities of cesarean section, early preterm labor, stillbirth, gestational hypertension, and female gender. In a study which survey comparing adverse birth risks with maternal age in over 2 million women; stillbirth, preterm birth, neonatal death, congenital anomaly, and low birth weight was found to increase with maternal age (15). In most previous studies, the risks of pregnancies in adolescents and women of advanced age with regard to the maternal, fetal and neonatal outcomes have been separately investigated. And pregnancies at reproductive age extremes are generally considered in the high-risk pregnancy category $(1,2,3,4,16)$. Our study differs from those studies in that we classified maternal age three categories which include the control group.

Taking into consideration the current findings and previous Turkısh birth studies, although there is no meaningful increase in the rates of stillbirth and early preterm labor in women of advanced age, logistic regression analysis revealed that the age was a significant contributor rising the rates of stillbirth and early preterm labor. We thought that this was due to our definition of advanced maternal age as 40 . In accordance with increasing maternal age, several comorbid systemic disorders and uterine and placental abnormalities may play important roles affecting the course of pregnancy $(17,18,19)$. Obstetricians need to pay more attention to obstetric and medical histories of pregnant women of advanced age and their present health status.

According to changes in the obstetrical policies of our country, in future years, there may be improvements in maternal and neonatal health statistics, especially in pregnancies of adolescents and women of advanced age since the government accepted full support of perinatal and neonatal care of mothers and newborns as native and immigrant since 2012. In addition, continuing improvements in maternal and neonatal care are important goals of our healthcare system.

The findings of present study can be helpful for developing new strategies for reducing pregnancy-related mortality and morbidities, for the urban regions with similar demographic characteristics. Increasing public awareness about the complications and course of pregnancies in adolescents and women of advanced age may increase the knowledge level of mothers about the situations that they may encounter before and after delivery.

\section{REFERENCES}

(1) Pinheiro RL, Areia AL, Mota Pinto A, Donato H. Advanced Maternal Age: Adverse Outcomes of Pregnancy, A Meta-Analysis. Acta Med Port. 2019 29;32(3):219-226.

(2) Fitzpatrick KE, Tuffnell D, Kurinczuk JJ, Knight M. Pregnancy at very advanced maternal age: a UK population-based cohort study. BJOG. 2017 ;124(7):1097-1106.

(3) Marvin-Dowle K, Soltani H. A comparison of neonatal outcomes between adolescent and adult mothers in developed countries: A systematic review and meta-analysis. Eur J Obstet Gynecol Reprod Biol X. 2020 3; 6: 100109.

(4) Indarti J, Al Fattah AN, Dewi Z, Hasani RDK, Mahdi FAN et al.Teenage Pregnancy: Obstetric and Perinatal Outcome in 
a Tertiary Centre in Indonesia. Obstet Gynecol Int. 2020 26; 2020: 2787602.

(5) World Health Organization. The second decade: improving adolescent health and development. WHO, Department of Child and Adolescent Health and Development, Programme Brochure. Geneva; 1998.

(6) https://www.who.int/news-room/fact-sheets/detail/adolescent-pregnancy. 31 January 2020

(7) Althabe F, Moore JL, Gibbons L, Berrueta M, Goudar SS et al. Adverse maternal and perinatal outcomes in adolescent pregnancies: The Global Network's Maternal Newborn Health Registry study. Reprod Health. 2015;12 Suppl 2(Suppl 2):S8.

(8) Mathews TJ, Hamilton BE. Mean age of mother, 1970-2000. Natl Vital Stat Rep. 2002 11;51(1):1-13.

(9) Matthews TJ, Hamilton BE. Delayed childbearing: more women are having their first child later in life. NCHS Data Brief. 2009;(21):1-8.

(10) Bellieni C. The Best Age for Pregnancy and Undue Pressures. J Family Reprod Health. 2016 Sep;10(3):104-107.

(11) Türkiye Nüfus ve Sağlık Araştırması, 2008. www.hips.hacettepe.edu.tr/tnsa2008/

(12) Karabulut A, Ozkan S, Bozkurt Al, Karahan T, Kayan S. Perinatal outcomes and risk factors in adolescent and advanced age pregnancies: comparison with normal reproductive age women. J Obstet Gynaecol. 2013 ;33(4):346-50.

(13) Edirne T, Can M, Kolusari A, Yildizhan R, Adali E et al. Trends, characteristics, and outcomes of adolescent pregnancy in eastern Turkey. Int J Gynaecol Obstet. 2010;110(2):105-8.

(14) Giri A, Srivastav VR, Suwal A, Tuladhar AS. Advanced maternal age and obstetric outcome. Nepal Med Coll J. 2013 ;15(2):87-90.

(15) Weng YH, Yang CY, Chiu YW. Risk Assessment of Adverse Birth Outcomes in Relation to Maternal Age. PLoS One. 2014 10;9(12): e114843.

(16) Kuyumcuoglu U, Guzel Al, Celik Y. Comparison of the risk factors for adverse perinatal outcomes in adolescent age pregnancies and advanced age pregnancies. Ginekol Pol. 2012 ;83(1):33-7.

(17) Lean SC, Derricott H, Jones RL, Heazell AEP. Advanced maternal age and adverse pregnancy outcomes: A systematic review and meta-analysis. PLoS One. 2017 17;12(10): e0186287.

(18) Salihu HM, Wilson RE, Alio AP, Kirby RS. Advanced maternal age and risk of antepartum and intrapartum stillbirth. J Obstet Gynaecol Res. 2008;34(5):843-50.

(19) Carolan M. Maternal age $\geq 45$ years and maternal and perinatal outcomes: a review of the evidence. Midwifery. 2013 ;29(5):479-89. 